\title{
Cadmium Modification of Nucleolar Ultrastructure and RNA Synthesis in Physarum polycephalum ${ }^{1}$
}

\author{
J. F. SINA ${ }^{2}$ AND B. CHIN \\ Department of Environmental and Industrial Health, University of Michigan, Ann Arbor, Michigan 48109
}

Received May 24, 1977; accepted August 3, 1977

\begin{abstract}
Cadmium Modification of Nucleolar Ultrastructure and RNA Synthesis in Physarum polycephalum. SinA, J. F., AND Chin, B. (1978). Toxicol. Appl. Pharmacol. 43, 449-459. Exposure of the acellular slime mold Physarum polycephalum to cadmium resulted in distortion of nucleolar structure and in inhibition of RNA synthesis. The extent of these lesions was dependent on concentration of cadmium, as well as duration and timing of exposure in the cell cycle. A 30-min exposure to $5 \times 10^{-4} \mathrm{M} \mathrm{CdSO}_{4}$, initiated just as DNA synthesis began, inhibited RNA synthesis by $50 \%$ and caused subtle nucleolar changes: eccentric placement of nucleoli in nuclei, and the appearance of multiple nucleolar bodies in low incidence. Exposure to either $5 \times$ $10^{-4} \mathrm{M}$ or $1.5 \times 10^{-3} \mathrm{M} \mathrm{CdSO}_{4}$ for $4 \mathrm{hr}$ depressed RNA synthesis to $20-25 \%$ of control values and caused ring-shaped nucleoli. In electron micrographs of cadmium-treated cells, nucleoli appeared as electron dense rings of nucleolar material enclosing less intensely staining central zones, in contrast to control nucleoli which appeared as uniformly dense, nearly spherical bodies. Three-dimensional reconstructions showed that the "ring" was, in actuality, a sphere of nucleolar material completely surrounding a central cavity. A 4-hr exposure to $5 \times 10^{-4}$ or $1.5 \times$ $10^{-3} \mathrm{M} \mathrm{CdSO}_{4}$ after postmitotic reconstruction was complete and DNA synthesis had been underway for $2 \mathrm{hr}$ or more inhibited RNA synthesis by $50 \%$, but nucleolar rings were not formed. These observations identify the nucleus as a target for cadmium, or for effectors which mediate cadmium toxicity, and they suggest that disruption of nucleolar function (i.e., synthesis of RNA) and/or of nucleolar structure may be underlying mechanisms of cadmium toxicity.
\end{abstract}

The physiological effects of cadmium exposure have been characterized as follows: Short-term acute exposures damage target organs such as kidney (Emmerson, 1970; Singhal et al., 1976), liver (Singhal et al., 1976), and testis (Pařizek, 1957), while longterm chronic exposures are associated with hypertension (Schroeder et al., 1966), emphysema (Snider et al., 1973), and osteomalacia (Emmerson, 1970). Biochemical manifestations of cadmium toxicity include proteinuria (Vigliani, 1969; Piscator, 1962), aminoaciduria (Singhal et al., 1976), glucosuria (Singhal et al., 1976), and lowered hepatic glycogen (Schroeder et al., 1966). Although deaths from cadmium exposure have been reported as early as 1938 (Bulmer and Rothwell, 1938), mechanisms of cadmium toxicity, especially at the cellular level, are just beginning to be elucidated.

\footnotetext{
${ }^{1}$ This study was supported by USPHS Grant No. GM 00803 from the National Institute of Environmental Health Sciences.

${ }^{2}$ This study was carried out in partial fulfillment of requirements for a Ph.D. degree (for JFS) at the University of Michigan, supported by Environmental Health Sciences Research Training Grant No. 5T01 ES 00138 from the National Institute of Environmental Health Sciences.
} 
These studies may be complicated by the presence of cadmium-binding metalloprotein (metallothionein), which is considered to be an accommodative vehicle for protecting the cell (Rugstad and Norseth, 1975; Leber and Miya, 1976), but which recent reports show is itself toxic under certain conditions (Cherian et al., 1976; Webb and Etienne, 1977).

Physarum polycephalum offers a simple and suitable system for studying cellular mechanisms of cadmium toxicity. Experimental subjects are derived from a single plasmodium: one cell containing many naturally synchronous nuclei in a common cytoplasm bounded by a single membrane. The membrane is self-sealing, which allows many replicate discs of standard size to be cut from one plasmodium (Chin et al., 1972). Since synchrony is maintained between them, replicate discs are essentially identical. The system offers additional advantages: amplification of biochemical events via natural synchrony and precision in determining the position of the organism in the cell cycle, both of which allow greater definition in correlating biochemical and structural events with toxicity. A final point is that our laboratory has been unable to detect a low molecular weight, $\left[{ }^{109} \mathrm{Cd}\right]$-binding protein (metallothionein) in this organism (unpublished results), further simplifying the interpretation of results. Bryan and Hidalgo (1976) have implicated the nucleus as an intracellular target of cadmium in rat liver by showing that cadmium is bound to the nucleus prior to being sequestered by metallothionein. In this communication we report studies on nuclear structure and function in cadmium exposed $P$. polycephalum.

\section{METHODS}

Physarum polycephalum, strain $\mathrm{M}_{3} \mathrm{CV}$, was maintained in microplasmodial form in submerged culture in an axenic medium (Chin and Bernstein, 1968) at $23^{\circ} \mathrm{C}$. For experiments, the organism was cultured as plasmodia on the surface of liquid media (Chin et al., 1972). Synchronized plasmodia were formed by fusing a thick slurry of water-washed microplasmodia on dry filter paper for $4 \mathrm{hr}$. The first synchronous mitosis subsequent to fusion occurred $7.5 \mathrm{hr}$ after addition of medium. The first complete cell cycle was terminated $14 \mathrm{hr}$ later. The timing of mitosis was determined by phasecontrast microscopic observation of wet mounts, prepared at regular intervals by squashing a small piece of plasmodium in a drop of salt solution with a spatula (Daniel and Baldwin, 1964). Early prophase, with a duration of $10 \mathrm{~min}$, served as the endpoint to identify mitosis precisely. The marker for early prophase was the disintegrating nucleolus, which was crescent shaped and eccentric against the nuclear membrane, standing out in clear contrast to the nucleoplasm.

At the appropriate point in the cell cycle, determined by experimental design, replicate discs were cut from the growing edge of a plasmodium with a cork borer (Chin et al., 1972). Exposures were made by floating discs on $15 \mathrm{ml}$ of medium containing $\mathrm{CdSO}_{4}(\mathrm{pH} 4.70)$ and $/$ or $5 \mu \mathrm{Ci} / \mathrm{ml}$ of $\left[5_{-}{ }^{3} \mathrm{H}\right]$ uridine. ${ }^{3}$ Exposure was terminated by lifting the discs from exposure medium and washing them on fresh medium ( $\mathrm{pH} \mathrm{4.75).}$

Replicate discs were solubilized in $1 \mathrm{ml}$ of ice-cold $0.4 \mathrm{~N} \mathrm{NaOH}$. Macromolecular fractions were prepared by addition of $7 \mathrm{ml}$ of ice-cold trichloroacetic acid-acetone [ 1

${ }^{3}\left[5^{3} \mathrm{H}\right] \mathrm{Urd}, \mathrm{sp}$ act, $21 \mathrm{Ci} / \mathrm{mmol}$; Nuclear Dynamics, Inc., El Monte, Calif. 
volume $20 \%$ trichloroacetic acid (w/v) plus 1 volume acetone]. The acid-precipitable fraction was separated by centrifugation at $7700 \mathrm{~g} \times 15 \mathrm{~min}$, washed by resolubilization and reprecipitation, and finally dissolved in $1 \mathrm{ml}$ of $\mathrm{NaOH}$. Aliquots were diluted for determination of protein content (Lowry et al., 1951) on a Technicon AutoAnalyzer. Radioactivity, in $0.1-\mathrm{ml}$ aliquots mixed with $5 \mathrm{ml}$ of PCS cocktail, ${ }^{4}$ was measured in a Packard Tri-Carb liquid scintillation spectrometer. Incorporation of $\left[5-{ }^{3} \mathrm{H}\right]$ Urd into RNA in cadmium-treated and control replicate discs was compared on the basis of counts per minute per milligram of protein.

For chemical determination of RNA, acid-precipitable material was resuspended in $\mathrm{NaOH}$ and stored at $4{ }^{\circ} \mathrm{C}$ overnight. During this interval, $92 \pm 0.5 \%(n=8)$ of the total cellular RNA, as measured by incorporated $\left[5-{ }^{3} \mathrm{H}\right] \mathrm{Urd}$, became acid soluble. DNA and protein were precipitated by addition of $10 \%$ trichloroacetic acid $(\mathrm{w} / \mathrm{V})$ and separated by centrifugation. The acid-soluble fraction was diluted for measuring RNA content by the orcinol reaction (Horecker, 1957), using AMP and sedoheptulosan as standards.

The incidence of nucleolar lesions was quantitated in nuclear preparations obtained by differential centrifugation of plasmodial homogenates through sucrose step gradients

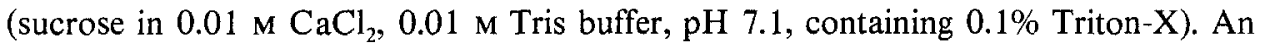
entire plasmodium was homogenized in a Potter-Elvehjem tissue grinder in $20 \mathrm{ml}$ of $0.15 \mathrm{M}$ buffered sucrose and filtered to remove large debris and slime. Homogenate, 5 $\mathrm{ml}$, was underlayed with $10 \mathrm{ml}$ of $0.25 \mathrm{M}$ buffered sucrose and spun in a Sorvall centrifuge (HS-4 swinging bucket rotor) at $100 \mathrm{~g} \times 10 \mathrm{~min}$. The pellet was resuspended in $5 \mathrm{ml}$ of $0.25 \mathrm{M}$ sucrose, underlayed with $10 \mathrm{ml}$ of $1 \mathrm{M}$ buffered sucrose, and centrifuged, again at $100 \mathrm{~g} \times 10 \mathrm{~min}$. Nuclei were found in a white cloud in the $1 \mathrm{~m}$ sucrose layer and in the pellet. The top of the gradient, which contained cell debris, was removed down to the white cloud. The remainder of the gradient was centrifuged at $1850 \mathrm{~g} \times 5 \mathrm{~min}$, to obtain a pellet in which the content of nuclei was enriched. The pellet was resuspended in $0.25 \mathrm{M}$ buffered sucrose and processed for nuclei once more, for further enrichment. The final pellet was transferred to a glass slide in a minimum of homogenizing medium, and the relative numbers of normal and damaged nucleoli were determined under phase-contrast optics.

For light and electron microscopy, replicate discs were fixed for $1 \mathrm{hr}$ at room temperature with cacodylate-buffered, glutaraldehyde- $\mathrm{OsO}_{4}$ (Daniel and Järlfors, 1972). After fixation, discs were washed, dehydrated in ethanol to propylene oxide, and infiltrated slowly by passage through increasing concentrations of Araldite/Epon in propylene oxide over a 36-hr period [Araldite/Epon was modified from Hayat (1970) by omission of dibutyl phthalate]. The samples were embedded in flat molds and polymerized at $60-65^{\circ} \mathrm{C}$ for 2 days. Samples for light microscopy were sectioned on a LKB Huxley ultramicrotome at $0.5-1.0 \mu \mathrm{m}$ thickness, mounted on glass slides, and stained with $0.1 \%$ toluidine blue in $1 \% \mathrm{Na}_{2} \mathrm{~B}_{4} \mathrm{O}_{7}$. Observations were made with a Zeiss photomicroscope with phase optics. Electron microscopy samples were sectioned at silver/gold thickness, picked up on Formvar-carbon coated grids, and stained either with $7 \%$ uranyl magnesium acetate (Frasca and Parks, 1965) or in a 1:1 mixture of aqueous $7 \%$ uranyl acetate and absolute ethanol, followed by lead citrate (Reynolds, 1963). Sections were viewed on an AEI Corinth electron microscope at $60 \mathrm{kV}$.

${ }^{4}$ Amersham/Searle, Arlington Heights, Ill. 


\section{RESULTS}

The cell cycle of Physarum polycephalum ${ }^{5}$ is initiated at early prophase with a brief (20 min) period of mitosis, followed immediately by a period of DNA synthesis (approximately $3 \mathrm{hr}$ ), then a period of preparation for mitosis, and, finally, the next mitosis (Nygaard et al., 1960). Exposure of the organism to $\mathrm{CdSO}_{4}$ concentrations below $10^{-4} \mathrm{M}$ at any time during the cell cycle was not visibly toxic; $10^{-2} \mathrm{M}$, however,
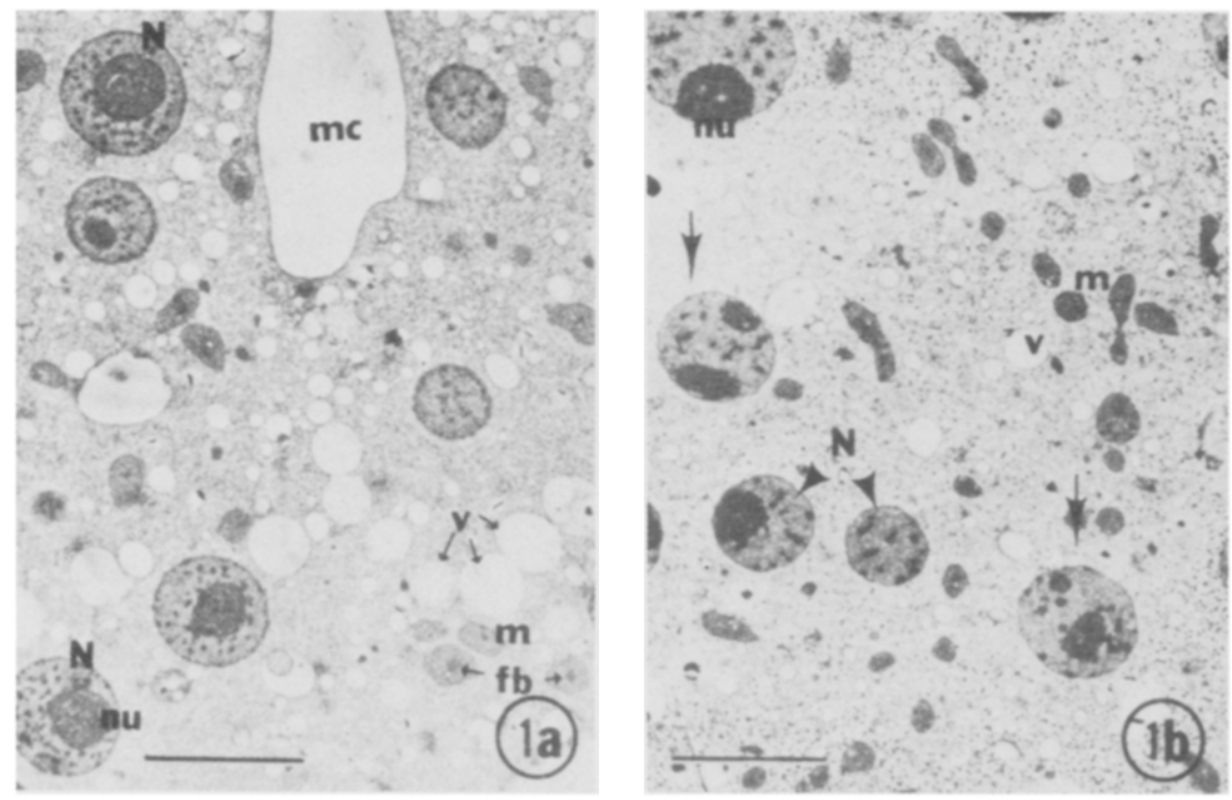

FIG. 1. (a) Electron micrograph of control replicate disc of Physarum polycephalum, 4 hr after mitosis: microchannels $(\mathrm{mc})$; intracellular vacuoles $(\mathrm{v})$; mitochondria $(\mathrm{m})$ with fibrous body (fb); nucleus $(\mathrm{N})$; nucleolus (nu). $\times 3240$. (b) Electron micrograph of replicate disc $3.5 \mathrm{hr}$ after $30 \mathrm{~min}$ of exposure to $5 \times$ $10^{-4} \mathrm{M} \mathrm{CdSO}_{4}$. Note the occurrence of multiple nucleolar bodies (arrows). Bars indicate $5 \mu \mathrm{m} . \times 3240$.

was lethal. Exposure to $5 \times 10^{-4} \mathrm{M} \mathrm{CdSO}_{4}$ for $30 \mathrm{~min}$ at EP, followed by $3.5 \mathrm{hr}$ of incubation on fresh medium containing $\left[5-{ }^{3} \mathrm{H}\right] \mathrm{Urd}$, depressed incorporation of radioactivity to $50 \%$ of control values: control $=2054 \mathrm{cpm} / \mathrm{mg}$ of protein \pm 44 (SD), $n=6$; cadmium exposed $=1031 \pm 90, n=6$. When exposure was extended to $4 \mathrm{hr}$, the inhibition of $\left[5-{ }^{3} \mathrm{H}\right] \mathrm{Urd}$ incorporation was greater, falling to $20 \%$ of control values: control $=1137 \pm 158, n=3$; cadmium exposed $=217 \pm 30, n=3$. Ultrastructurally, the cytoplasmic contents in control (Fig. 1a) and in cadmium-treated (Fig. 1b) cells appeared to be the same. However, while each control nucleus contained a centrally located, nearly spherical, uniformly dense nucleolus, each cadmium-treated nucleus contained an eccentric, slightly irregular nucleolus, and some nuclei contained multiple nucleolar bodies. Since individual nucleolar bodies did not stain differentially or exhibit distinctive textural characteristics, we could not ascertain whether each represented a

\footnotetext{
${ }^{5}$ Points of reference in the Physarum cell cycle are: early prophase (EP), mitosis (M), DNA synthesis $(\mathrm{S})$, preparation for mitosis $\left(\mathrm{G}_{2}\right)$.
} 
fragment of a single nucleolus or a separate, intact nucleolus. Under light microscopy, multiple nucleolar bodies appeared to be present in approximately $10 \%$ of the nuclei.

Exposure of replicate discs to $1.5 \times 10^{-3} \mathrm{M} \mathrm{CdSO}_{4}$ for $1 \mathrm{hr}$ from EP inhibited [5$\left.{ }^{3} \mathrm{H}\right]$ Urd incorporation to $76 \%$ of controls: control $=575 \pm 57, n=4$; cadmium exposed $=$ $439 \pm 19, n=4$. Exposure of replicates to $1.5 \times 10^{-3} \mathrm{M}$ cadmium for $2 \mathrm{hr}$ from EP inhibited [ $\left.5-{ }^{3} \mathrm{H}\right]$ Urd incorporation to $42 \%$ of control values: control $=1332 \pm 106, n=$ 4; cadmium exposed $=558 \pm 21, n=4$. Exposure for $4 \mathrm{hr}$ depressed $\left[5-{ }^{3} \mathrm{H}\right] \mathrm{Urd}$

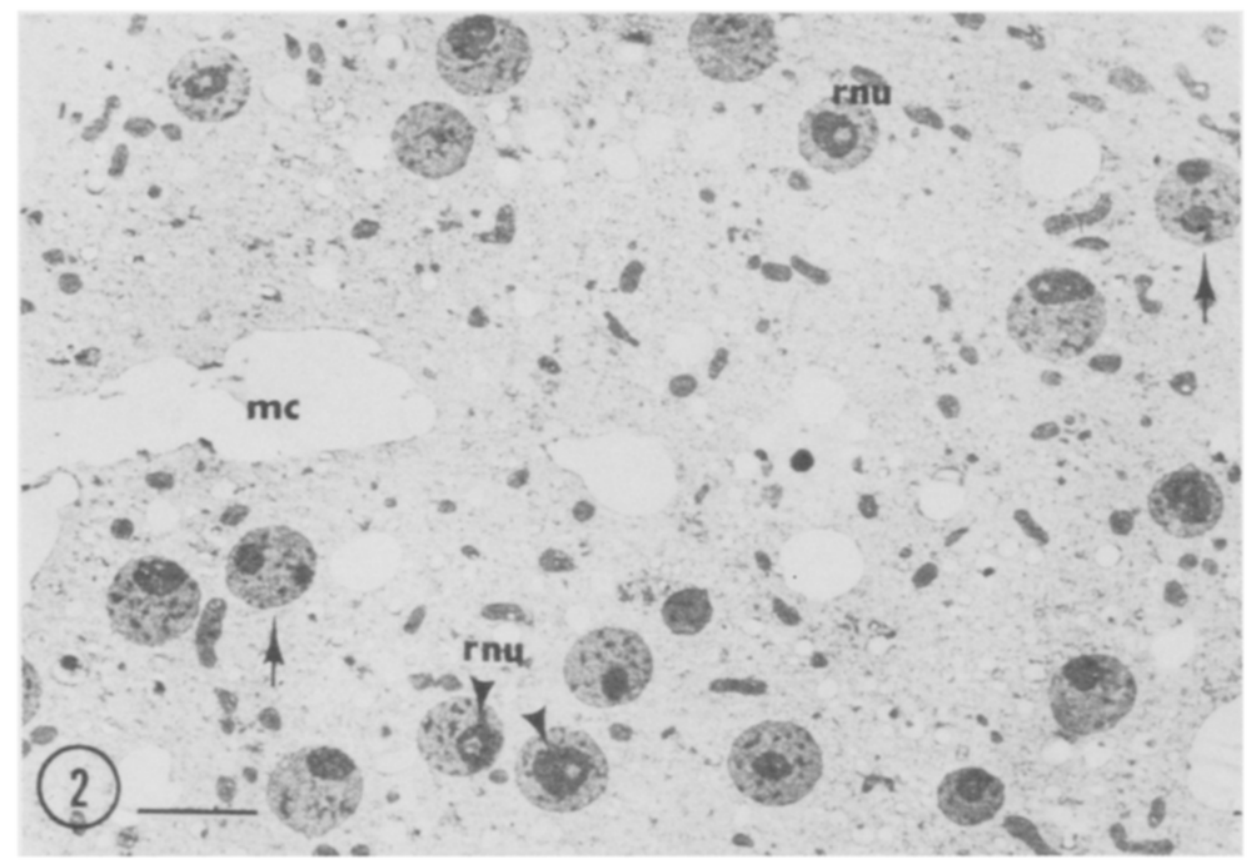

FIG. 2. Cell exposed to $1.5 \times 10^{-3} \mathrm{M} \mathrm{CdSO}_{4}$ for $4 \mathrm{hr}$ beginning at early prophase. Note that many nucleoli are in close proximity to the nuclear membrane and that multiple nucleolar bodies are present in some nuclei (arrows). The predominate lesion, however, is the ring-shaped nucleoli (rnu). Microchannels $(\mathrm{mc})$. Bar indicates $5 \mu \mathrm{m}$. $\times 2430$.

incorporation to $20-30 \%$ : control $=8903 \pm 547, n=4$; cadmium exposed $=2206 \pm$ $454, n=4$. Orcinol determination after $4 \mathrm{hr}$ exposure to $1.5 \times 10^{-3} \mathrm{M}$ cadmium at EP showed that RNA content was depressed by $60 \%$ : control at zero time $=15.1 \mu \mathrm{g}$ of pentose $\pm 1.5, n=6$; control after $4 \mathrm{hr}=17.1 \pm 1.7, n=6$; cadmium exposed after 4 $\mathrm{hr}=15.9 \pm 2.2, n=6$. At this concentration of cadmium, the eccentric location of nucleoli was emphasized, but the incidence of nuclei with multiple nucleolar bodies remained low (Fig. 2, arrows). Moreover, as the concentration of cadmium or the length of exposure to the salt increased, distortion of nucleolar structure progressed beyond eccentric displacement and the formation of multiple nucleolar bodies to the appearance of "ring-shaped" nucleoli (Fig. 2). A typical control nucleolus (Fig. 3a) appeared as a uniformly dense assortment of fibrillar and granular materials (Bernhard, 1966). In cadmium-treated cells, however, these components of nucleolar structure were segregated and arranged in a ring, surrounding a central area of low electron density 

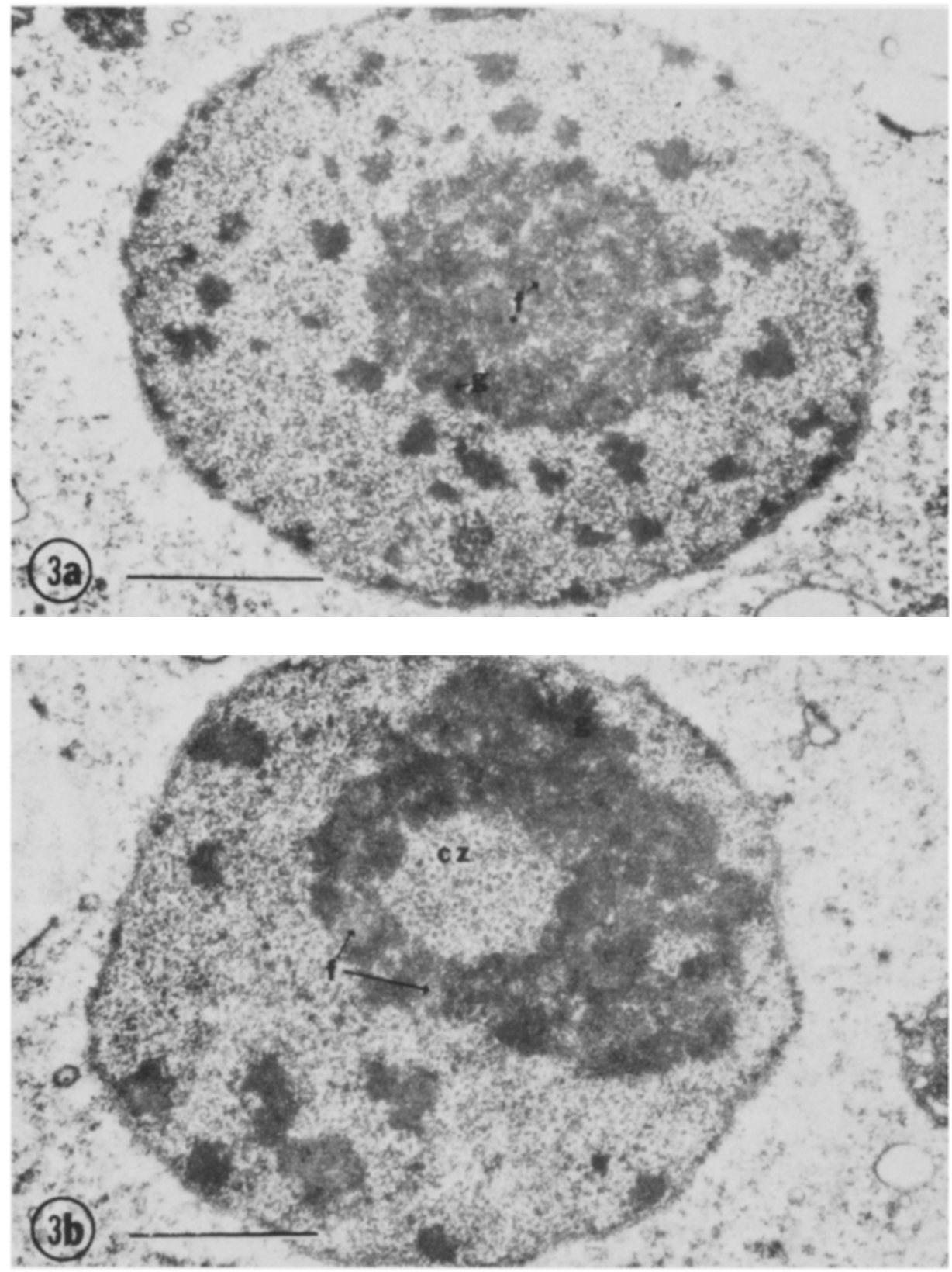

FIG. 3. Comparison of nuclei of (a) control and (b) $1.5 \times 10^{-3} \mathrm{M} \mathrm{CdSO}_{4}$-treated cells. In both cases, a heterogeneous assortment of fibrillar ( $\mathrm{f}$ ) and granular $(\mathrm{g})$ components can be distinguished. The cadmiumtreated cells, however, show the occurrence of a central zone $(\mathrm{cz})$ with lower electron density, similar to that of the nucleoplasm. Bars indicate $1 \mu \mathrm{m} . \times 25,100$. 
(Fig. 3b). Figure 4 shows the discrete grouping of fibrillar and granular components into zones of differential electron density, both within the ring-shaped nucleolus and in smaller fragments of nucleolar material.

Ring-shaped nucleoli were studied in $1-\mu \mathrm{m}$-thick serial sections cut from cadmiumtreated cells. Pictures were taken of the same field in consecutive sections for reconstruction of ring-shaped nucleoli in three-dimensional wax models and in drawings. These reconstructions revealed that the ring nucleolus was, in actuality, an irregular sphere, completely surrounding a central zone which did not stain for RNA,

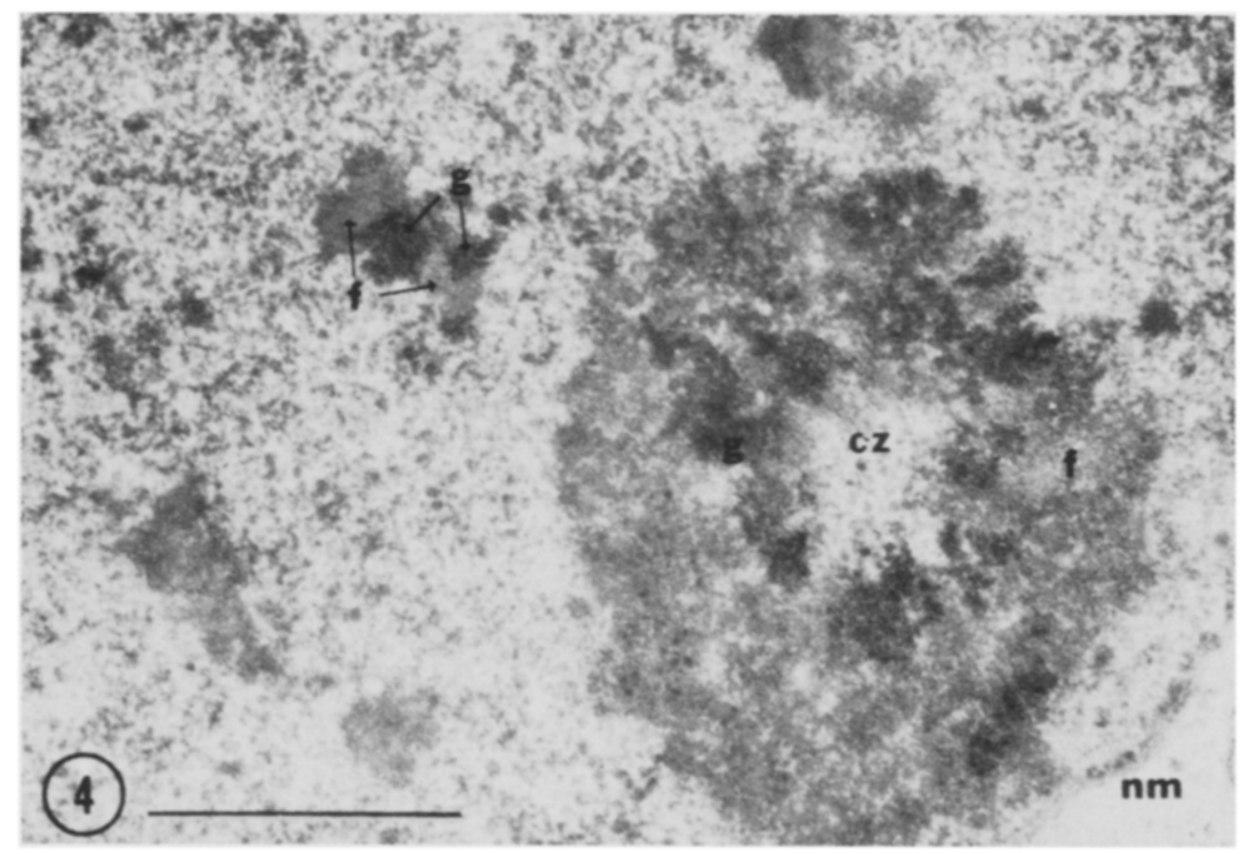

FIG. 4. Electron micrograph of ring nucleolus at higher magnification, slightly underprinted to show the segregation of fibrillar $(\mathrm{f})$ and granular $(\mathrm{g})$ components: central zone (cz); nuclear membrane (nm). Bar indicates $0.5 \mu \mathrm{m} . \times 63,900$.

and which had no continuity with the nucleoplasm (Fig. 5). For purposes of comparison with the literature, this structure will be referred to as "ring" nucleoli, even though we know the nucleolus is hollow, with respect to RNA.

A count of 1500 control and 1500 cadmium-treated nuclei in enriched nuclear preparations showed that ring nucleoli occurred in $70 \%$ of the nuclei of cells exposed to $1.5 \times 10^{-3} \mathrm{M} \mathrm{CdSO}_{4}$ for $4 \mathrm{hr}$, compared to $3-5 \%$ in controls. At this level of exposure, nuclei with multiple nucleolar bodies appeared at only slightly greater incidence in cadmium exposed replicate discs $(8 \%)$ than in controls $(2 \%)$. In order to confirm that these results were not artifacts of the enrichment procedure, nuclei were examined in situ in $1-\mu \mathrm{m}$-thick sections. From cadmium-exposed cells, 600 control and 600 nuclei were scored. These counts indicated that the enrichment data were, if anything, a bit conservative. Of nucleoli in cadmium-treated discs, $80-90 \%$ were in ring form, 
compared with $3-5 \%$ in controls. The incidence of ring nucleoli was dependent on the concentration of cadmium. Of nucleoli, $40-50 \%$ were in ring form following exposure of the organism to $5 \times 10^{-4} \mathrm{M}$ cadmium for $4 \mathrm{hr}$ from $\mathrm{EP}$.

Exposure of $4 \mathrm{hr}$ to $\mathrm{ZnSO}_{4}$ in concentrations up to $10^{-1} \mathrm{M}$ did not produce ring nucleoli.

When exposures were initiated later in $\mathrm{S}$, the numbers of ring nucleoli observed at the end of $4 \mathrm{hr}$ decreased. When exposure was initiated $2 \mathrm{hr}$ after EP, the lesion did not

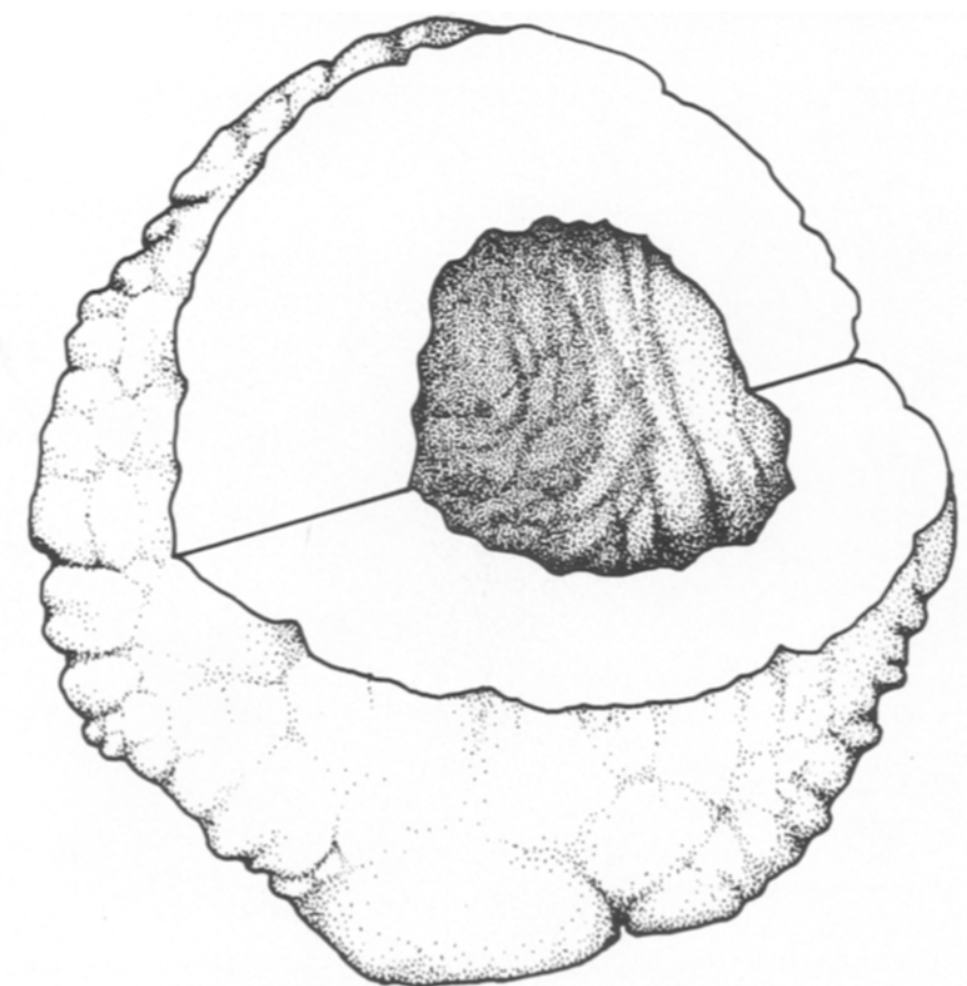

FIG. 5. Artist's representation of a typical ring nucleolus reconstructed from serial sections. (nuclear membrane stripped away). Note that the central zone (darkest portion) is neither centrally located nor entirely spherical.

develop. However, a 2-hr exposure to $1.5 \times 10^{-3} \mathrm{M} \mathrm{CdSO}_{4}$ initiated at EP was sufficient for development of nucleolar rings, if an additional 1-2 hr incubation on cadmium-free medium was allowed.

Exposure of replicate discs to $5 \times 10^{-4} \mathrm{M}$ cadmium for $4 \mathrm{hr}$ in $\mathrm{G}_{2}$ inhibited $\left[5^{-3} \mathrm{H}\right.$ ] Urd incorporation by $60 \%$ : control $=7273 \mathrm{cpm} / \mathrm{mg}$ of protein $\pm 917, n=4$; cadmium exposed $=2445 \pm 150, n=4$. Exposure of discs to $1.5 \times 10^{-3} \mathrm{M}$ cadmium for $4 \mathrm{hr}$ in $\mathrm{G}_{2}$ inhibited $\left[5^{-3} \mathrm{H}\right] \mathrm{Urd}$ incorporation by $54 \%$ : control $=1879 \pm 374, n=4$; cadmium exposed $=872 \pm 69, n=4$. Orcinol determination showed that a 4-hr exposure to $1.5 \times$ $10^{-3} \mathrm{M} \mathrm{CdSO}_{4}$ depressed RNA content by $53 \%$ : control at zero time $=18.0 \mu \mathrm{g}$ of pentose $\pm 4.4, n=6$; control after $4 \mathrm{hr}=27.5 \pm 5.2, n=8$; cadmium exposed after 4 $\mathrm{hr}=22.4 \pm 4.8, n=8$. The development of ring nucleoli, however, was unique to $\mathrm{S}$. When replicate discs were exposed to either concentration of cadmium in early and late 
$\mathrm{G}_{2}$, few, if any, ring nucleoli developed after $4 \mathrm{hr}$ of exposure, although nucleoli did assume eccentric positions and a few multiple nucleolar bodies were noted. Replicate discs were exposed to $1.5 \times 10^{-3} \mathrm{M}$ cadmium for $4 \mathrm{hr}$ in $\mathrm{G}_{2}, 5 \mathrm{hr}$ prior to mitosis. Half the cells were removed from cadmium and allowed to go through division on fresh medium, while the other half were continued on cadmium-containing medium. Those replicate discs which were reincubated on fresh medium contained 5-10\% ring-shaped nucleoli upon completion of division and reconstruction; those with continuous incubation on cadmium contained $70-90 \%$ ring nucleoli.

To study recovery from the nucleolar lesion, replicate discs were exposed to $1.5 \times$ $10^{-3} \mathrm{M}$ cadmium for $4 \mathrm{hr}$ from EP to induce ring-shaped nucleoli and were then transferred to fresh medium and incubated. Progress through the cell cycle was monitored by following the morphological changes associated with mitosis (Guttes et al., 1968). Ring nucleoli persisted through the $G_{2}$ period without recovery of normal structure. Ring structures were still apparent as cadmium-exposed discs began to undergo changes associated with mitosis. However, after mitosis, when nucleoli were reconstructed, nucleoli in cells exposed to cadmium were indistinguishable from those in control cells.

\section{DISCUSSION}

The results reported here show that exposure of Physarum polycephalum to cadmium interfered with nucleolar structure and function. While cytoplasmic ultrastructure appeared normal in cadmium-treated cells, a continuum of nucleolar aberrancies developed with increasing concentration and duration of cadmium exposure, progressing from eccentric nucleoli and multiple nucleolar bodies to ring-shaped nucleoli. In parallel, RNA synthesis was progressively inhibited by higher concentrations of and longer exposures to cadmium. This study focused on the development of ring nucleoli, which resulted when a 4 -hr exposure to $1.5 \times 10^{-3} \mathrm{M}$ cadmium was made in early $\mathrm{S}$. At this time, the nucleolus was undergoing reconstruction after mitosis (Guttes et al., 1968) and the synthesis of DNA and RNA [a major nucleolar component (Busch and Smetana, 1970)] were just getting underway. Under these conditions, RNA synthesis, as measured by precursor incorporation and by chemical determination, was inhibited approximately $80 \%$. When cadmium exposure was made prior to EP or $2 \mathrm{hr}$ or more after EP, the nucleolar lesions were more subtle and RNA synthesis was inhibited to a lesser extent. The data suggest that there is a cellular event(s) unique to the first $2 \mathrm{hr}$ of $\mathrm{S}$ and sensitive to cadmium, which, when damaged, leads to the formation of ring nucleoli and to the inhibition of RNA synthesis. These lesions may be coincidental expressions of an underlying toxic mechanism, or may be causal, one to the other. Further, the recovery data suggested that the organism had to pass through $\mathrm{S}$ for recovery to occur, suggesting not only that the formation of ring nucleoli was dependent upon an event in $\mathbf{S}$ but also that repair of the lesion was dependent on an event in this particular time period.

Abnormal nucleolar ultrastructure, including ring nucleoli, is often observed where RNA synthesis is atypical. In cultured tobacco cells (Johnson, 1969), ring nucleoli are approximately three times more active in RNA synthesis than normal nucleoli. Conversely, in human smooth muscle cells (Smetana et al., 1970) and lymphocytes (Smetana et al., 1968), the occurrence of ring nucleoli is associated with reduced 
synthesis of RNA. In Jerusalem artichoke tubers (Rose et al., 1972), vacuolation of nucleoli is at a maximum when RNA synthesis is falling. More important to this work, ring nucleoli appear in $P$. polycephalum (Gontcharoff and Rao, 1972) when RNA synthesis is inhibited by fluoro-deoxyuridine immediately after mitosis. Gontcharoff and Rao suggest that the ring structure results from interference with a transcription product of DNA which is replicated early in S. This nucleolar lesion is very similar to the one observed in this study.

In vitro studies have shown that cadmium can alter the conformation and properties of DNA and RNA by binding to both phosphates and bases in nucleic acids (Singhal $e t$ al., 1976; Vallee and Ulmer, 1972). Sissoëff et al. (1976) have shown in various plant and animal tissues that cadmium is bound preferentially to reiterative DNA sequences (ribosomal DNA) and that higher amounts of bound ion are found in tumor cells. Webb et al. (1972) reported that $70-90 \%$ of the cation is associated with the nucleus of tumor cells, and $50 \%$ of this is specifically bound to the nucleolus when primary rhabdomyosarcomata are induced in rat by intramuscular implantation of cadmium.

We hypothesize that distortion of structure of the nucleolus and impairment of its function are basic cellular effects of cadmium toxicity and propose a mechanism by which these lesions may occur: in early S, cadmium interferes with nuclear DNA (possibly by binding) (a) to disrupt the nucleolar organizing region, which determines nucleolar structure (Busch and Smetana, 1970) and/or (b) to interfere with the transcription of rRNA [some of which may be necessary for reconstruction of daughter nucleoli (Busch and Smetana, 1970; Guttes et al., 1968)]. Either (a) or (b) independently, or both together, could result in decreased RNA synthesis and abnormal nucleolar structure. In $\mathrm{G}_{2}$, cadmium interferes with RNA synthesis, but, since the nucleolus is not undergoing reconstruction, the structural integrity of the organelle is not dependent on normal RNA synthesis or proper function of the nucleolar organizing region, and ring nucleoli do not develop.

\section{REFERENCES}

BERNHARD, W. (1966). Ultrastructural aspects of the normal and pathological nucleolus in mammalian cells. Nat. Cancer Inst. Monogr. 23, 13-38.

Bryan, S. E., AND Hidalgo, H. A. (1976). Nuclear ${ }^{115} \mathrm{cadmium:} \mathrm{Uptake} \mathrm{and} \mathrm{disappearance}$ correlated with cadmium-binding protein synthesis. Biochem. Biophys. Res. Commun. 68, $858-866$.

Bulmer, F. M. R., AND Rothwell, H. E. (1938). Industrial cadmium poisoning: A report of fifteen cases, including two deaths. Canad. Pub. Health J. 29, 19-26.

Busch, H., And Smetana, K. (1970). The Nucleolus. Academic Press, New York.

Cherian, M. G., Goyer, R. A., and Delaquerriere-Richardson, L. (1976). Cadmiummetallothionein-induced nephropathy. Toxicol. Appl. Pharmacol. 38, 399-408.

CHIN, B., AND BERnSTEIN, I. A. (1968). Adenosine triphosphate and synchronous mitosis in Physarum polycephalum. J. Bacteriol. 96, 330-337.

Chin, B., Friedrich, P. D., And Bernstein, I. A. (1972). Stimulation of mitosis following fusion of plasmodia in the myxomycete Physarum polycephalum. J. Gen. Microbiol. 71, 93101.

Daniel, J. W., And Baldwin, H. H. (1964). Methods in Cell Physiology (D. M. Prescott, ed.), Vol. I. Academic Press, New York.

DANIEl, J. W., AND JÄrLFORS, U. (1972). Plasmodial ultrastructure of the myxomycete Physarum polycephalum. Tissue Cell. 4, 15-36. 
Emmerson, B. T. (1970). "Ouch-Ouch" Disease: the osteomalacia of cadmium nephropathy. Ann. Int. Med. 73, 854-855.

Frasca, J. M., AND Parks, V. R. (1965). A routine technique for double-staining ultrathin sections using uranyl and lead salts. J. Cell Biol. 25, 157-161.

GontcharofF, M., AND RAO, B. (1972). Dependence of the nucleolar structure on DNA and RNA synthesis. Chromosoma (Berlin). 38, 441-457.

GutTes, S., Gutres, E., AND Ellis, R. A. (1968). Electron microscope study of mitosis in Physarum polycephalum. J. Ultrastruct. Res. 22, 508-529.

Hayat, M. A. (1970). Principles and Techniques of Electron Microscopy. Biological Applications. Vol. 1. Van Nostrand Reinhold, New York.

HORECKER, B. L. (1957). The orcinol reaction for mixtures of pentose and heptulose. In Methods in Enzymology (S. P. Colowick and N. O. Kaplan, eds.), Vol. III, pp. 105-107. Academic Press, New York.

Johnson, J. M. (1969). A study of nucleolar vacuoles in cultured tobacco cells using radioautography, actinomycin D, and electron microscopy. J. Cell Biol. 43, 197-206.

LEber, A. P., AND MIYA, T. S. (1976). A mechanism for cadmium- and zinc-induced tolerance to cadmium toxicity: Involvement of metallothionein. Toxicol. Appl. Pharmacol. 37, 403414.

Lowry, O. H., Rosebrough, N. R., Farr, A. L., and Randall, R. J. (1951). Protein measurement with the Folin phenol reagent. J. Biol. Chem. 193, 265-275.

NyGaARD, O., GutTes, S., AND Rusch, H. P. (1960). Nucleic acid metabolism in a slime mold with synchronous mitosis. Biochim. Biophys. Acta 38, 298-306.

PǍ̌izeK, J. (1957). The destructive effect of cadmium ion on testicular tissue and its prevention by zinc. J. Endocrinol. 15, 56-63.

Piscator, M. (1962). Proteinuria in chronic cadmium poisoning. Arch. Environ. Hlth. 4, 607621.

Reynolds, E. S. (1963). The use of lead citrate at high pH as an electron-opaque stain in electron microscopy. J. Cell Biol. 17, 208-212.

Rose, R. J., SetTerfield, G., ANd Fowke, L. C. (1972). Activation of nucleoli in tuber slices and the function of nucleolar vacuoles. Exp. Cell Res. 71, 1-16.

Rugstad, H. E., AND Norseth, T. (1975). Cadmium resistance and content of cadmiumbinding protein in cultured human cells. Nature (London) 257, 136-137.

Schroeder, H. A., Kroll, S. S., Little, J. W., Livingston, P. O., and Myers, M. A. G. (1966). Hypertension in rats from injection of cadmium. Arch. Environ. Hlth. 13, 788-789.

Singhal, R. L., Merali, Z., And HrdinA, P. D. (1976). Aspects of the biochemical toxicology of cadmium. Fed. Proc. 35, 75-80.

SissoëFF, I., Grisvard, J., AND Guillè, E. (1976). Presence of divalent cations bound to reiterative DNA sequences in higher plant and animal tissues. In Progress in Differentiation Research (N. Müller-Bérat, ed.), pp. 197-204. North-Holland, Amsterdam.

SmetanA, K., Freireich, E. J., AND Busch, H. (1968). Chromatin structures in ring-shaped nucleoli of human lymphocytes. Exp. Cell Res. 52, 112-128.

Smetana, K., Gyorkey, F., Gyorkey, P., And Busch, H. (1970). Studies on the ultrastructure of nucleoli in human smooth muscle cells. Exp. Cell Res. 60, 175-184.

Snider, G. L., Hayes, J. A., Korthy, A. L., AND Lewis, G. P. (1973). Centrilobular emphysema experimentally induced by cadmium chloride aerosol. Amer. Rev. Respir. Dis. 108, 40-48.

V ALLEE, B. L., AND Ulmer, D. D. (1972). Biochemical effects of mercury, cadmium, and lead. Annu. Rev. Biochem. 41, 91-128.

Vigliani, E. C. (1969). The biopathology of cadmium. Amer. Ind. Hyg. Assoc. J. 30, 329-340.

WebB, M., Heath, J. C., AND Hopkins, T. (1972). Intranuclear distribution of the inducing metal in primary rhabdomyosarcomata induced in the rat by nickel, cobalt, and cadmium. Brit. J. Cancer 26, 274-278.

Webe, M., And Etienne, A. T. (1977). Studies on the toxicity and metabolism of cadmiumthionein. Biochem. Pharmacol. 26, 25-30. 